\title{
EDDY CURRENT INSPECTION RESULTS ON WORK ROLLS FOR FINISHING STANDS OF HOT STRIP MILL*
}

Alberto Tremea ${ }^{1}$

\begin{abstract}
The eddy current system is universally recognized as a most suitable method to point out discontinuities or modifications on the roll surface. The automation of the controls through the implementation of sophisticated equipments on the grinding machine has favoured its employment in the roll shop. A big effort is still going on to clarify the best way to promptly identify situations that could be really unsafe for the roll life. The results presented in this paper have been obtained through an intensive activity conducted in field by Innse Cilindri on work rolls of finishing stands of hot strip mills. The correct interpretation of the eddy current signals and a good calibration of the automatic system have allowed, in many cases, a substantial optimisation of regrinding practices.
\end{abstract}

Key Words: Work roll; Eddy current system; Bruise signal; Roll redressing.

${ }^{1}$ R\&D Dept. - Innse Cilindri Srl - Via A. Franchi 20, 25127 Brescia, Italy. 


\section{INTRODUCTION}

This paper discusses the use of automatic eddy current inspection to examine the roll surface defects in order to optimize redressing procedures. The roll surface condition at the end of the campaign in terms of damage level (scratches, cracks, pits, microspalling, etc.) was compared with the results of the eddy current system. The attention will be focused in the front stands of hot strip mills where the roll surface degradation is the most important parameter to establish the roll behavior. High Chromium Iron $(\mathrm{HCrl})$ and High Speed Steel (HSS) are the class of roll material now in use. Table 1 summarized where and how is the relative employment between these 2 families of roll materials: the use of HSS rolls is very common particularly in stainless steel rolling while for carbon steel production an equilibrium still survive between two classes of material.

Table 1 Roll Materials in front stands of HSM

\begin{tabular}{|c|c|c|c|}
\hline $\begin{array}{c}\text { Rolled } \\
\text { Material }\end{array}$ & F1-F2 & F3-F4 & F5-F... \\
\hline Carbon Steel & $70 \% \mathrm{HSS}$ & $30 \% \mathrm{HSS}$ & trials \\
\hline $\begin{array}{c}\text { Stainless } \\
\text { Steel }\end{array}$ & $100 \% \mathrm{HCrl}$ & $\begin{array}{l}70 \% \mathrm{HSCl} \\
80 \% \mathrm{HSS} \\
20 \% \mathrm{HCrl}\end{array}$ & trials \\
\hline
\end{tabular}

Mills that had adopted fully HSS rolls in the earlier stands are moving their use also in the intermediate stands where the wear resistance is a crucial problem (Figure 1). In these stands the roll material has to guarantee a sufficient wear resistance to carry out the rolling program without generates any problem to the strip in terms of profile and surface quality. The working temperatures and the friction phenomena typical in these stands require roll material with excellent high-temperature strength. In the first stands also the damaging due to thermal fatigue influence the roll life because it contributes in establishing the roll surface quality with all the consequences on campaign length and redressing procedures. The use of HSS rolls makes possible, in many situations, to perform longer campaign (or multiple) in comparison with $\mathrm{HCrl}$ rolls. HSS rolls show an optimal attitude in profile retain that together a low roughness of it assure excellent roll performance.

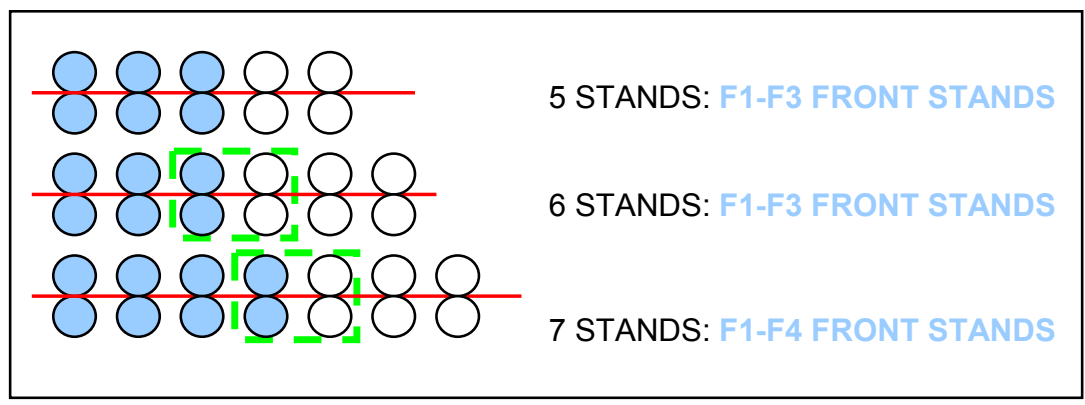

Figure 1 Finishing group configurations in a HSM 


\section{ROLL MATERIALS}

The rolls produced by Innse for the front stands of HSM are bimetallic cast rolls in $\mathrm{HSS}$ and $\mathrm{HCrl}$ with a vertical centrifugal machine; the core of these rolls is normally poured in nodular cast iron.

$\mathrm{HCrl}$ materials are white irons with a large amount of carbides rich in $\mathrm{Cr}$. These carbides, called $\mathrm{Cr}_{7} \mathrm{C}_{3}$, characterize all the properties of this material: their quantity establishes the hardness and indirectly the properties of ferrous matrix. Generally to improve the characteristics of strength at high temperature elements like Mo (W), V are added. The heat treatment represents an important step in the production of these special cast irons: only it optimization, in respect to particular chemistry, makes possible obtaining of a very performing material. The microstructures of $\mathrm{HCrl}$ is characterized by the presence of large eutectic $\mathrm{Cr}$ carbides placed along grain boundaries while into the martensitic matrix there are small carbides (secondary carbides) useful to support the rolling stresses. The addition of strong carbide formers elements like $\mathrm{V}$ and $\mathrm{Nb}$ allows the precipitation of hard primary carbides within the dendrites that improving the capability of the matrix to withstand the rolling loads. Table 2 points out the typical ranges about chemical composition and hardness of $\mathrm{HCrl}$ for rolls.

The family of HSS rolls is very large. HSS materials are based on combinations of carbon, chromium, vanadium, molybdenum, tungsten and sometimes niobium. Due to specific relative amount of alloying elements the microstructure of these steels (so the properties) can be very different. The presence of complex carbides with different shape and hardness gives a series of steels with singular optimizing characteristics so there is a possibility to choose (or to try) different materials in attempt to answer at specific needs (or problems) of the rolling stands. The balancing between carbide and matrix hardness is the most important key to produce an HSS roll with optimal technological properties. Normally HSS rolls show the best resistance at high temperature among all the alloys employed but the real success of their use is influenced a lot by the specific operating conditions of the mill. Table 2 shows the wide range about HSS chemistry.

Table 2 Work roll material in finishing stands

\begin{tabular}{|c|c|c|c|c|c|c|c|c|}
\hline \multirow{2}{*}{ MATERIAL } & \multicolumn{6}{|c|}{ MAIN ELEMENTS [wt\%] } & \multirow{2}{*}{ MICROSTRUCTURE } & \multirow{2}{*}{$\begin{array}{c}\text { HARDNESS } \\
\text { [ShC] }\end{array}$} \\
\hline & C & $\mathrm{Si}$ & $\mathrm{Mn}$ & $\mathrm{Cr}$ & Weq & Veq & & \\
\hline $\mathrm{HCrl}$ & $2.5-3.0$ & $0.5-1.0$ & $0.5-1.0$ & $15-20$ & $1-6$ & $0-3$ & $\begin{array}{l}\text { CARBIDES } \\
\left(20-30 \% \text { mainly } \mathrm{M}_{7} \mathrm{C}_{3}\right) \\
\text { MARTENSITIC } \\
\text { MATRIX }\end{array}$ & $75-80$ \\
\hline HSS & $1.5-2.5$ & $0.5-1.0$ & $0.5-1.0$ & $3-8$ & $3-15$ & 3-8 & $\begin{array}{l}\text { CARBIDES } \\
\left(5-15 \% M_{x} C_{y}\right) \\
\text { MARTENSITIC } \\
\text { MATRIX }\end{array}$ & $75-85$ \\
\hline
\end{tabular}

Table 3 reports some characteristics of these two families of roll materials. It isn't so difficult to note the general better situation of HSS in respect of HCrl [1,2]. HSS rolls have a very high potentiality but also the cost is high then their use must be carefully 
optimizing. Figure 2 outlines the microstructures of these materials (see next page carbides in white, matrix in dark).

Table 3 Main important characteristics of roll materials

\begin{tabular}{|c|c|c|c|c|c|c|c|c|}
\hline & \multicolumn{4}{|c|}{ CARBIDES [vol\%] } & \multirow{2}{*}{$\begin{array}{c}\text { TENSILE } \\
\text { STRENGTH } \\
\text { [MPa] } \\
\text { RT } / 600^{\circ} \mathrm{C} \\
\end{array}$} & \multirow{2}{*}{$\begin{array}{c}\text { COMPRESSIVE } \\
\text { STRENGTH } \\
\text { [MPa] } \\
\text { RT/550 } / 50^{\circ} \mathrm{C} \\
\end{array}$} & \multirow{2}{*}{$\begin{array}{c}\text { YOUNG'S } \\
\text { MODULUS } \\
\text { [GPa] }\end{array}$} & \multirow{2}{*}{$\begin{array}{c}\text { THERMAL } \\
\text { FATIGUE } \\
\text { LIFE } \\
{\left[{ }^{\circ} \mathrm{C}\right]} \\
\end{array}$} \\
\hline & MC & $\mathrm{M}_{7} \mathrm{C}_{3}$ & $\mathrm{M}_{2} \mathrm{C}$ & TOT & & & & \\
\hline $\mathrm{HCrl}$ & $x$ & $X$ & $x$ & $20-30$ & $850 / 550$ & $2300 / 1600$ & 215 & 450 \\
\hline HSS & $\mathrm{X}$ & $x$ & $x$ & $5-15$ & $1000 / 750$ & $2100 / 1300$ & 230 & 550 \\
\hline
\end{tabular}
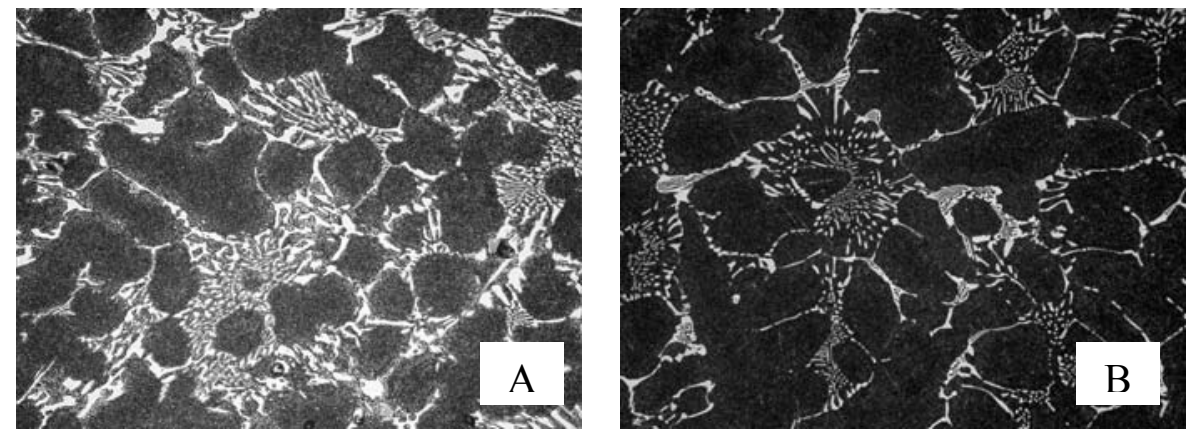

Figure 2 A - High Chromium Iron B - High Speed Steel (100x)

\section{EDDY CURRENT (EC) INSPECTION}

EC inspection is fundamental for today's strict mill requirements in safety and product quality. EC system has been used to accurately evaluate roll surface conditions. This system is a powerful roll inspection system designed to detect surface as well as subsurface defects with eddy current technology. Using an independent caliper on grinding machine, each eddy current scan can be performed during the normal grinding cycle, saving grinding time and reducing overall costs.

The EC system comes in many configurations; information on defects are stored with a very high resolution covering $100 \%$ of the roll barrel; for example it possible to have data every $2 \mathrm{~mm}$ along the roll barrel and 1.5 degrees around the roll circumference. This amount of information can be very useful for diagnosing the nature of the defects, like for example for differentiating thermal cracks from mechanical ones. In some case such system is able also to supervise machine vibration and dynamically balance the grinding wheel.

Automatic EC inspection can help to determine a more appropriate level of stock removal in relation to real roll surface damage. The output of the control is a map of the roll surface condition covering the entire roll barrel. This type of result, called "bruise", is in strict relation with the characteristics of the material so it gives the possibility to find area where modifications happen. The most important step is to verify what the system can find and measure it in some way.

The common steps of the procedure used to conduct the tests are summarized as follows:

1. accurate visual inspection of the roll surface at the end of the mill campaign;

2. roughness measurement; 
3. wear profile measurement;

4. light grinding pass and first EC inspection;

5. visual surface inspection and evaluation of surface damage (roughness measurement, micrographies of the surface, etc.);

6. rough grinding passes to remove roll wear while performing second EC inspection;

7. see step $n^{\circ} 5$;

8. finishing grinding passes to build the new roll profile while performing last EC inspection.

\section{RESULTS AND DISCUSSIONS}

The roll behavior, normally represented as roll performance, can be shown in different ways: mass or length of strip processed per millimeters of machined roll diameter or total tons of strip produced per roll campaign are only two examples. In the next paragraphs there are two examples about how to use EC controls to support activities during the redressing of the rolls.

\subsection{Hot Strip Mill 1}

Table 4 shows the results of Innse Cilindri rolls in 2 different periods in a HSM where there are in use $\mathrm{HCrl}$ rolls.

Table 4 Results of Innse Cilindri Rolls (HCrl F1-F4)

\begin{tabular}{|c|c|c|c|c|}
\hline Period & ton/campaign & $\begin{array}{c}\text { Theoretical } \\
\text { performance } \\
\text { [ton/mm] }\end{array}$ & $\begin{array}{c}\text { Real } \\
\text { performance } \\
\text { [ton/mm] }\end{array}$ & $\begin{array}{c}\text { Roll consumption } \\
\text { [mm/campaign] }\end{array}$ \\
\hline Year $x$ & 2400 & 5640 & 5340 & 0.45 \\
\hline Year y & 2440 & 6500 & 6100 & 0.40 \\
\hline
\end{tabular}

The standard grinding procedures in this roll shop are shown in Table 5. These indications must be followed when the EC inspection doesn't show abnormal conditions on the roll surface due to rolling accidents.

Table 5 Fixed amount of stock removal material

\begin{tabular}{|c|c|}
\hline STAND & $\begin{array}{c}\text { MINIMUM STOCK } \\
\text { REMOVAL }[\mathrm{mm}]\end{array}$ \\
\hline F1 & 0.40 \\
\hline F2 & 0.40 \\
\hline F3 & 0.30 \\
\hline F4 & 0.25 \\
\hline
\end{tabular}

Table 6 Situation of rolls in stand F1

\begin{tabular}{|c|c|c|c|c|}
\hline WEAR & \multicolumn{2}{|c|}{ CONSUMPTION [mm] } & $\mathrm{R}_{\mathrm{a}}[\square \mathrm{m}]$ & TYPE of SURFACE DAMAGE \\
\hline \multirow{2}{*}{$\begin{array}{c}\text { Not } \\
\text { appreciable }\end{array}$} & BOTTOM ROLL & TOP ROLL & \multirow{2}{*}{$2-5$} & \multirow{2}{*}{$\begin{array}{ll}\text { - } & \text { Thermal fatigue } \\
\text { - } & \text { Pitting } \\
\text { - } & \text { Peeling } \\
\text { - } & \text { Abrasion } \\
\end{array}$} \\
\hline & $<0.05$ & $<0.05$ & & \\
\hline
\end{tabular}


A hard dark scale covers the roll surface. The pattern of firecracks, due to thermal fatigue, appears clear on both rolls. The pitting seems to be heavier on the bottom roll. Pitting severity mainly influences the value of the roughness. At the end of campaign the rolls don't show wear (Figure 3). A description of the state of the roll after a campaign in $\mathrm{F} 1$ is in Table 6.

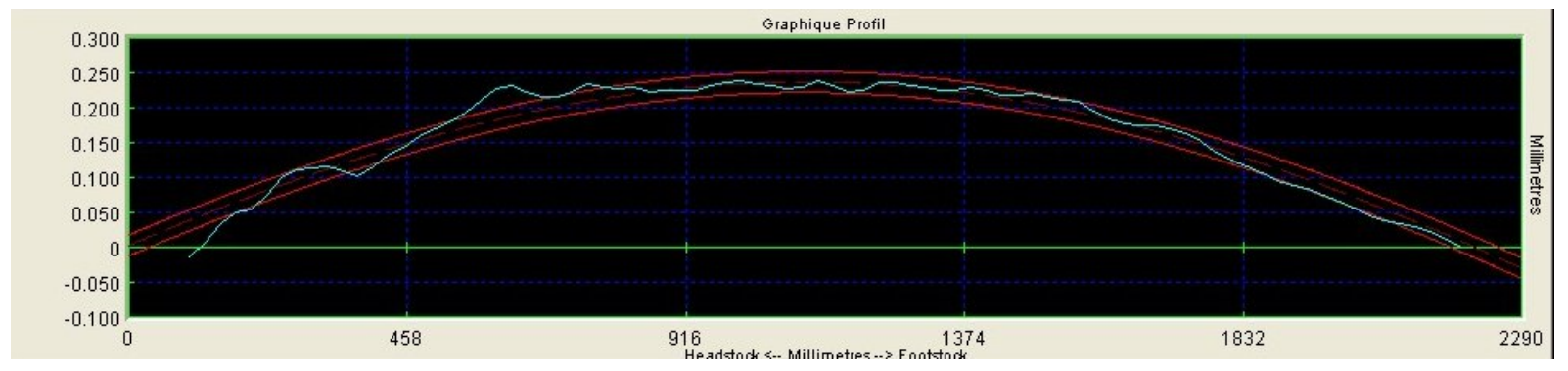

Figure 3 Wear profile of top roll after 2533ton in F1

Figure 4 shows the maps of the bruise signal of the EC system:

A. roll surface without removal grinding material - pitting is covered by the scale;

B. roll surface after a stock removal of $0.12 \mathrm{~mm}$ (midpoint of the barrel like reference) - circumferential bands with diffuse pitting (area of the pits about $0.5 \times 0.5 \mathrm{~mm}$ );

C. roll surface after a stock removal of $0.19 \mathrm{~mm}$ - isolated pits (area $<0.25 \times 0.25$ ). EC results don't point out the very fine pattern of firecracks due to thermal fatigue. The rough grinding passes can generate a raising of background noise takes itself very closely to the fixed thresholds (see case C in Figure 4).

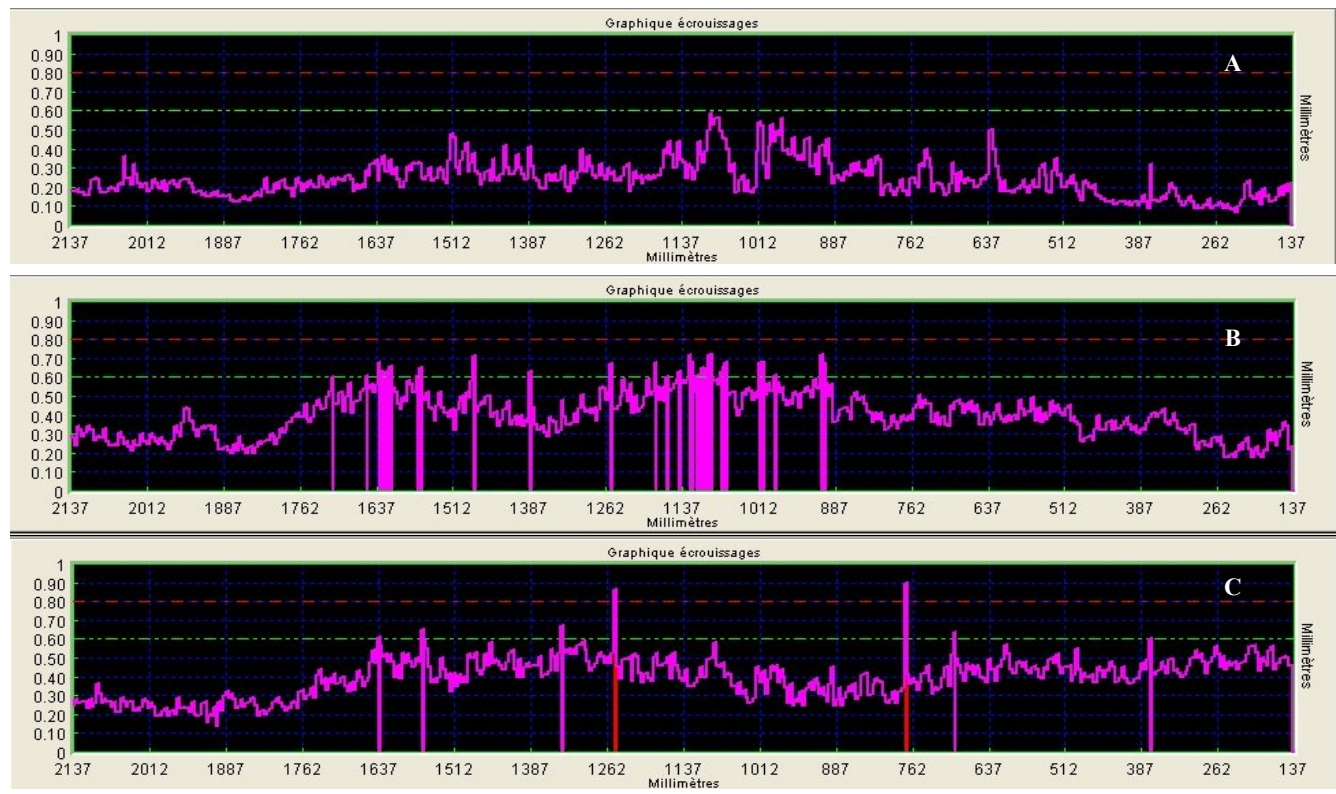

Figure 4 Bruise signal on F1 top roll surface 
Table 7 Situation of rolls in stand F2

\begin{tabular}{|c|c|c|c|c|}
\hline WEAR & \multicolumn{2}{|c|}{ CONSUMPTION [mm] } & $\mathrm{R}_{\mathrm{a}}[\square \mathrm{m}]$ & TYPE of SURFACE DAMAGE \\
\hline \multirow{2}{*}{$\begin{array}{c}\text { Not } \\
\text { appreciable }\end{array}$} & BOTTOM ROLL & TOP ROLL & \multirow[b]{2}{*}{$1.5-4$} & \multirow{2}{*}{$\begin{array}{ll}\text { - } & \text { Thermal fatigue } \\
\text { - } & \text { Peeling (Banding) } \\
\text { - } & \text { Pitting } \\
\text { - } & \text { Abrasion }\end{array}$} \\
\hline & $<0.05$ & $<0.05$ & & \\
\hline
\end{tabular}

In respect to the situation of stand $\mathrm{F} 1$, in stand $\mathrm{F} 2$ rolls show, with higher frequency, bands where the scale is peeled off. The presence of these areas without scale doesn't change the wear rate of the roll but worsen the roughness that can reach level of $5-6 \mu \mathrm{m}$ in terms of $\mathrm{R}_{\mathrm{a}}$. The two figures that follows show the roll surface and roll profile respectively while Table 7 summarized the state of the roll at the end of a typical campaign.

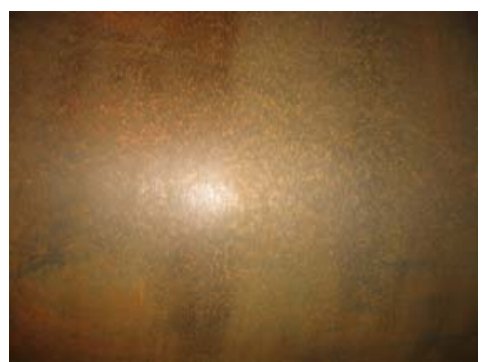

Figure 5 Surface aspect of the top roll after 2141 ton in stand F2 $\left(R_{a}=3.5 \mu \mathrm{m}\right)$

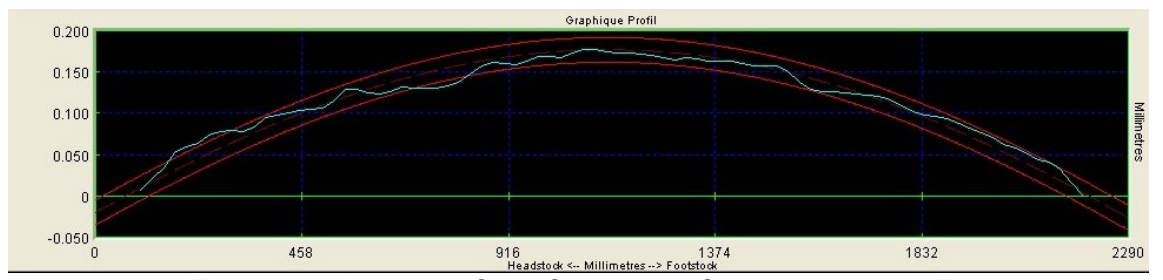

Figure 6 Wear profile of top roll after 2141ton in F2

Figure 7 shows the maps of the bruise signal of the EC system:

A. roll surface without removal grinding material - it's clear the region of the roll barrel affected from damaging;

B. roll surface after a stock removal of $0.14 \mathrm{~mm}$ - circumferential bands with diffuse pitting $(0.5 \times 0.5 \mathrm{~mm})$ where signals exceed the thresholds;

C. roll surface after a stock removal of $0.27 \mathrm{~mm}$ - no visible pits are present (size $<0.15 \times 0.15 \mathrm{~mm}$ ). The roughness on the right side of the barrel is $1.75 \mu \mathrm{m}$ while to the opposite side is $0.9 \mu \mathrm{m}$ : these differences could be responsible of the different levels of background noise in the map. 

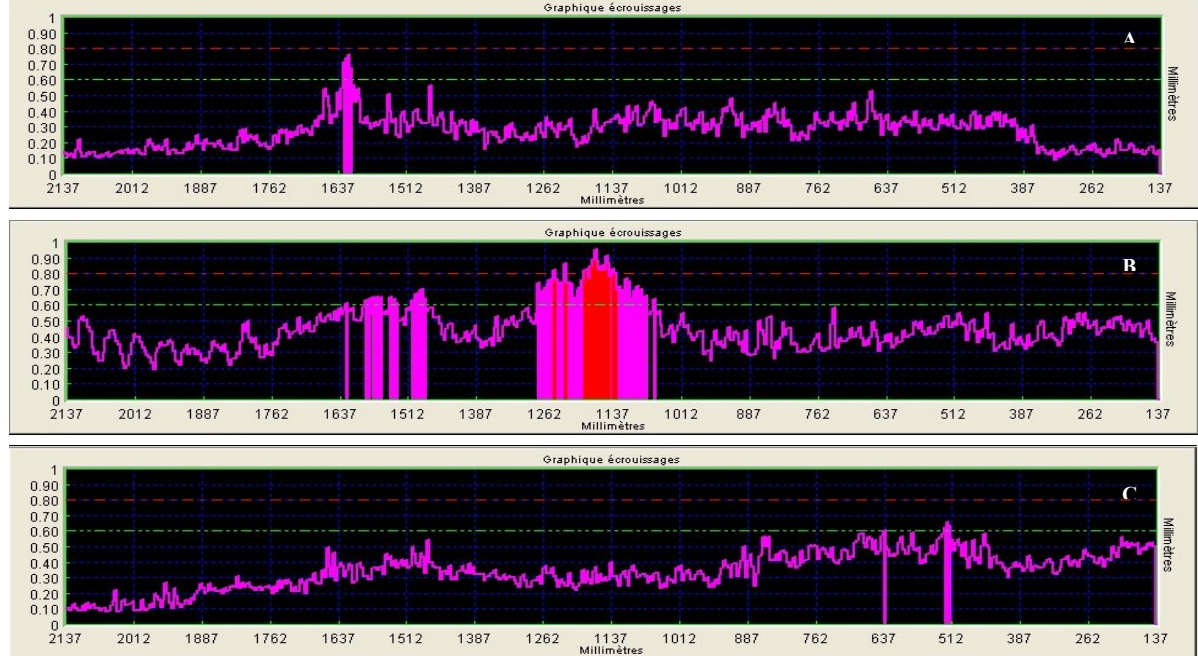

Figure 7 Bruise signal on F2 top roll surface
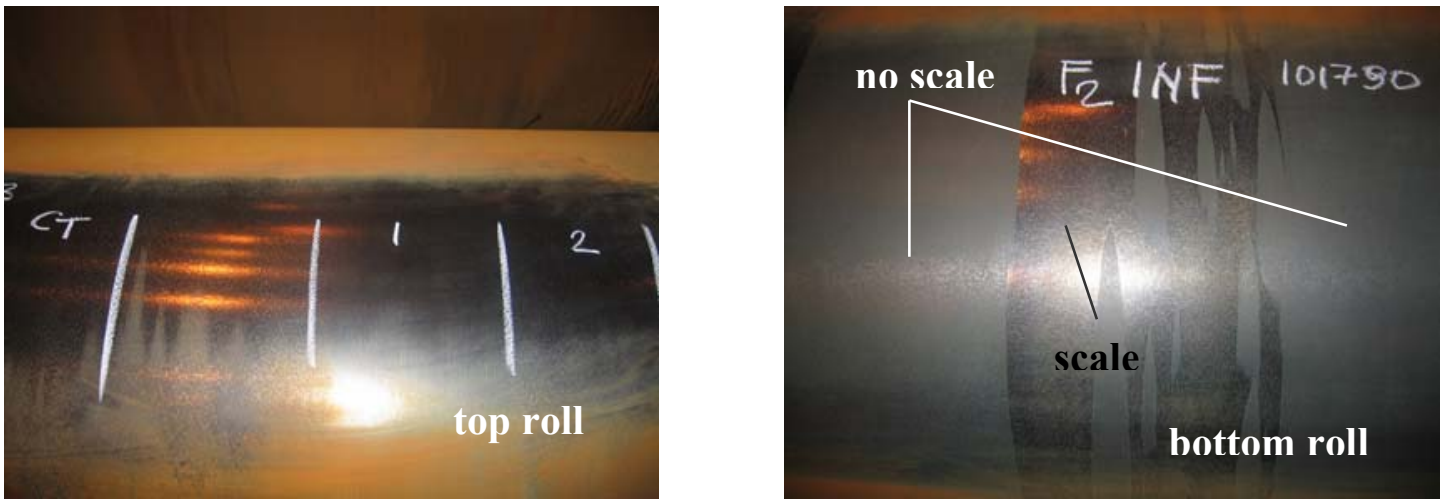

Figure 8 Surface aspect of the rolls after a campaign in stand F2

The Figure 9 shows the roughness profile of several bands damaging in different way (see the top roll in Figure 8). The scale still presents on the roll surface is abraded in different manner so to influence the roughness. In case of heavy peel of the roll scale (see the bottom roll in Figure 8), it possible to find a worsening of the quality of the surface but this doesn't create an appreciable change about the surface profile (Figure 10).

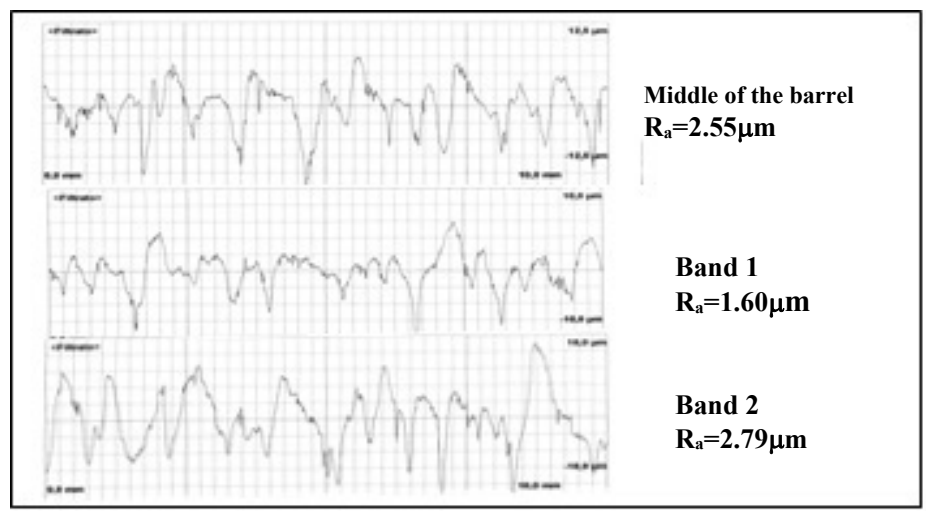

Figure 9 Roughness profiles of the top roll (see Figure 8) 


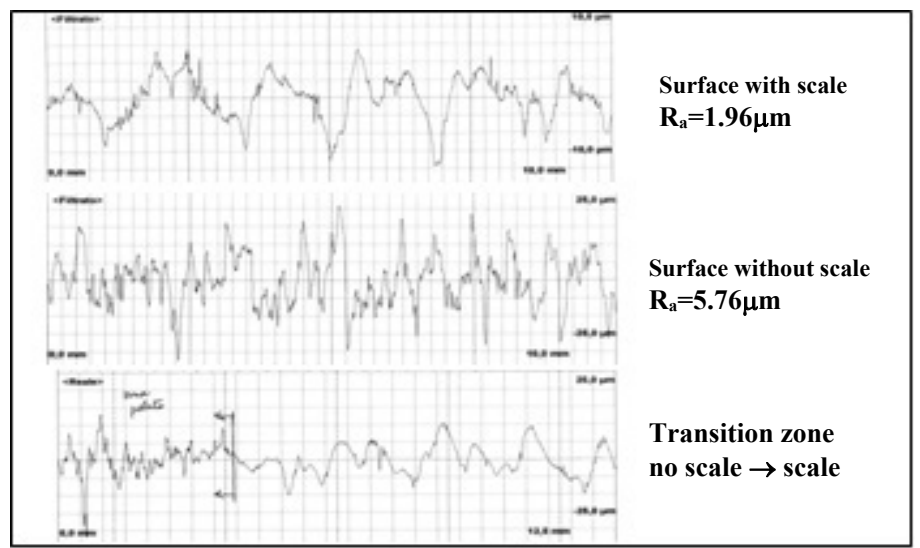

Figure 10 Roughness profiles of the bottom roll (see Figure 8)

Table 8 Situation of rolls in stand F3

\begin{tabular}{|c|c|c|c|c|}
\hline WEAR & \multicolumn{2}{|c|}{ CONSUMPTION [mm] } & $\mathrm{Ra}[\square \mathrm{m}]$ & TYPE of SURFACE DAMAGE \\
\hline \multirow{2}{*}{ Yes } & $\begin{array}{l}\text { BOTTOM } \\
\text { ROLL }\end{array}$ & TOP ROLL & \multirow{2}{*}{$2.5-3.5$} & \multirow{2}{*}{$\begin{array}{l}\text { - Abrasion } \\
\text { - Thermal fatigue } \\
\text { - Pitting }\end{array}$} \\
\hline & 0.07 & 0.05 & & \\
\hline
\end{tabular}

Rolls in stand F3 show an appreciable value of consumption, especially the bottom roll, but the loss of material normally doesn't exceed $0.15 \mathrm{~mm}$. Table 8 describes the typical condition of the roll at the end of campaign. Following figures point out a typical situation after a campaign in stand F3; with a very light extra grinding $(<0.10 \mathrm{~mm})$ the rolls appear in a good surface condition.
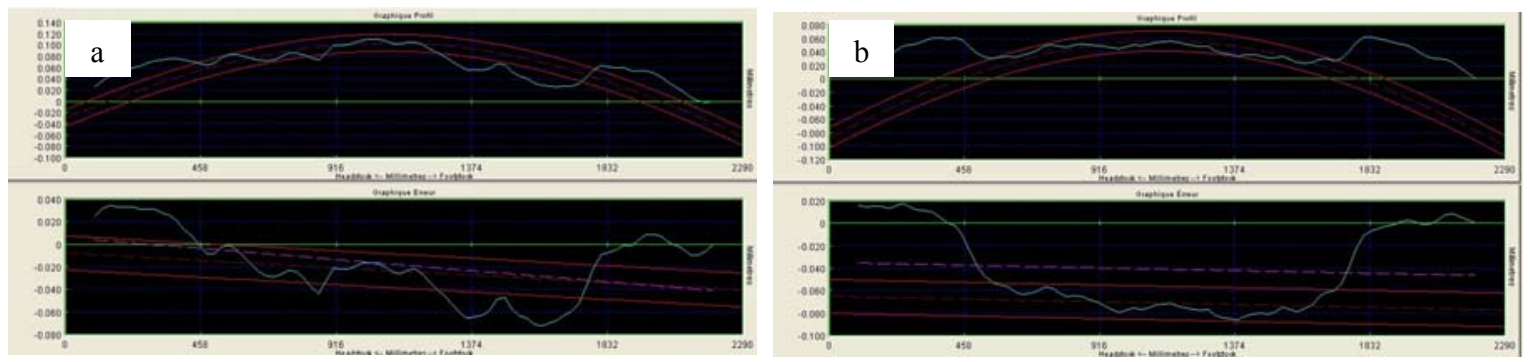

Figure 11 Wear profile of rolls after 2600ton in F3 (a-top; b-bottom)

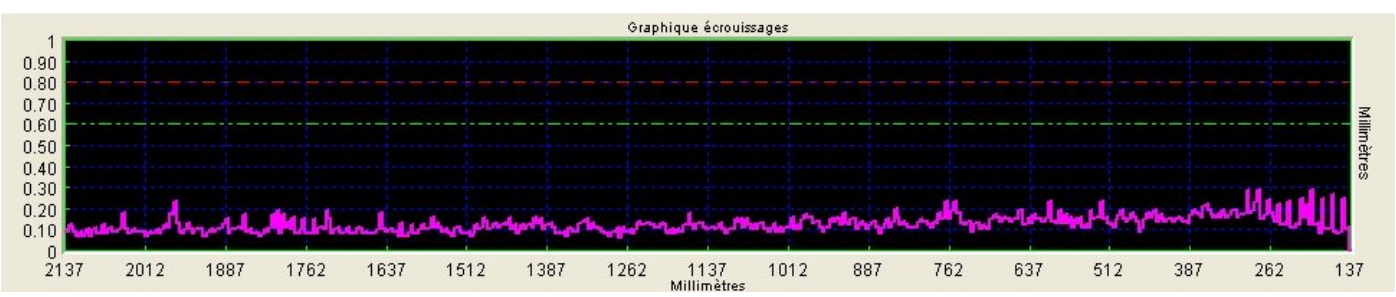

Figure 12 Bruise signal on F3 top roll surface after an extra grinding of $0.04 \mathrm{~mm}$ 


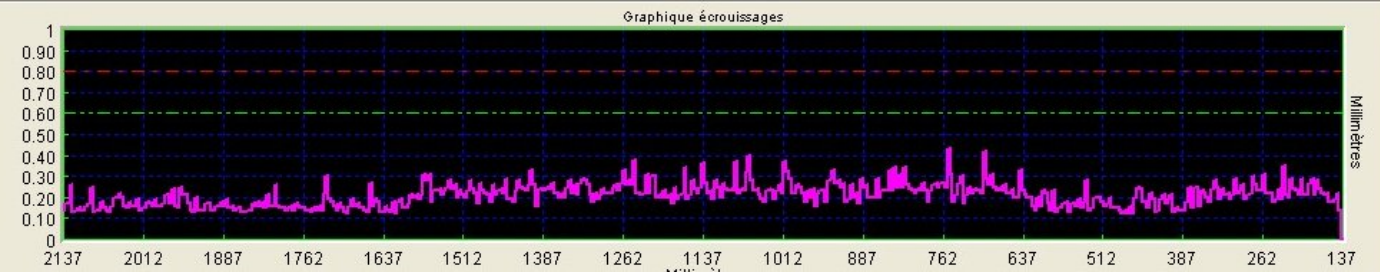

Figure 13 Bruise signal on F3 bottom roll surface after an extra grinding of $0.06 \mathrm{~mm}$

Table 9 Situation of rolls in stand F4

\begin{tabular}{|c|c|c|c|c|}
\hline WEAR & \multicolumn{2}{|c|}{ CONSUMPTION [mm] } & $\mathrm{Ra}[\square \mathrm{m}]$ & TYPE of SURFACE DAMAGE \\
\hline \multirow[t]{2}{*}{ Yes } & $\begin{array}{l}\text { BOTTOM } \\
\text { ROLL }\end{array}$ & TOP ROLL & \multirow[t]{2}{*}{$2.5-3.5$} & \multirow[t]{2}{*}{ - Abrasion } \\
\hline & 0.22 & 0.15 & & \\
\hline
\end{tabular}

Rolls in stand F4 show an important level of loss material during the campaign (higher in the bottom roll) and the wear profile appears several times irregular (Table 9). The amount of machined roll material is imposed from the roll consumption. In Figure 14 the surface aspect of a bottom roll after a campaign of 2561ton.

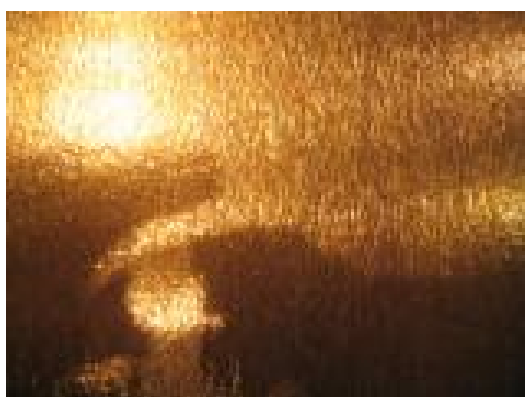

Figure 14 Bottom roll surface $\left(R_{a}=3.5 \mu \mathrm{m}\right)$

The wear profile showed in Figure 15 underline the typical level of consumption of a bottom roll in this stand. The principal scope of redressing procedures, for rolls working in F4, it's to rebuild their profile for the next campaign: done this also the roll surface it'll be ready for rolling (Figure 16).

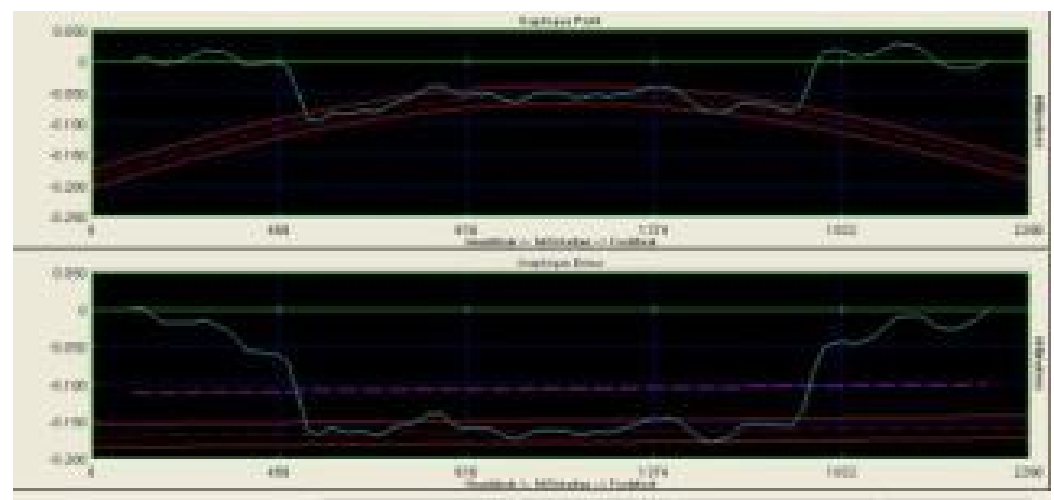

Figure 15 Wear profile of bottom roll after 2561ton in F4 

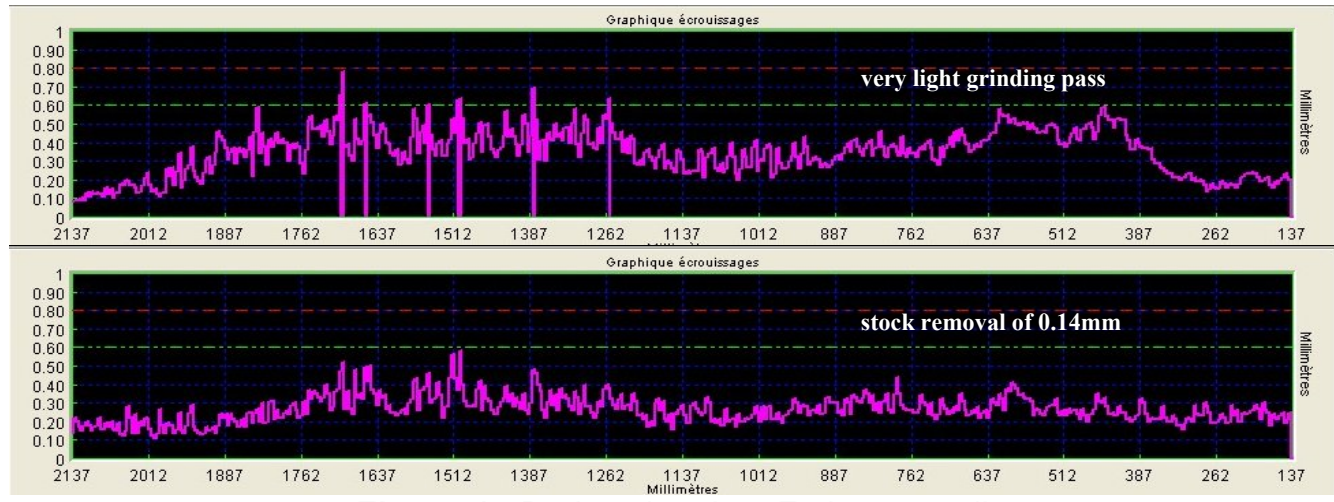

Figure 16 Bruise signal on F4 bottom roll

In this mill it's possible to summarize the major points relating to the utilization of the EC system to analyze the roll surface degradation as follow:

1. Stand F1-F2

o The automatic EC control isn't able to reveal the firecrazing of the roll surface generated to thermal fatigue.

o The automatic EC control is able to measure the level of the pitting.

o The automatic EC control doesn't show difference like background signal between roll surface with scale or without (peeled-off).

2. Stand F3-F4

o After the normal campaigns the main problem is the wear of the rolls (more pronounced in stand F4). The level of extra-grinding it's consequence of the level of wear profile uniformity. The scratches associated to the abrasion phenomena aren't so marked and then the roll surface appears free of defects after very light grinding passes.

\subsection{Hot Strip Mill 2}

In this mill in the first two stands are in use HSS rolls. In these stands campaigns are in the range of 5000-6000ton. Rolls, at the end of campaign, show thermal fatigue and pitting; wear is practically zero (Figure17). EC control results can be used to follow the level of roll surface damage during grinding. Figure 18 shows an example of EC signal sensitivity to the surface damaging of the roll (thermal fatigue plus micro pitting in Figure 19).

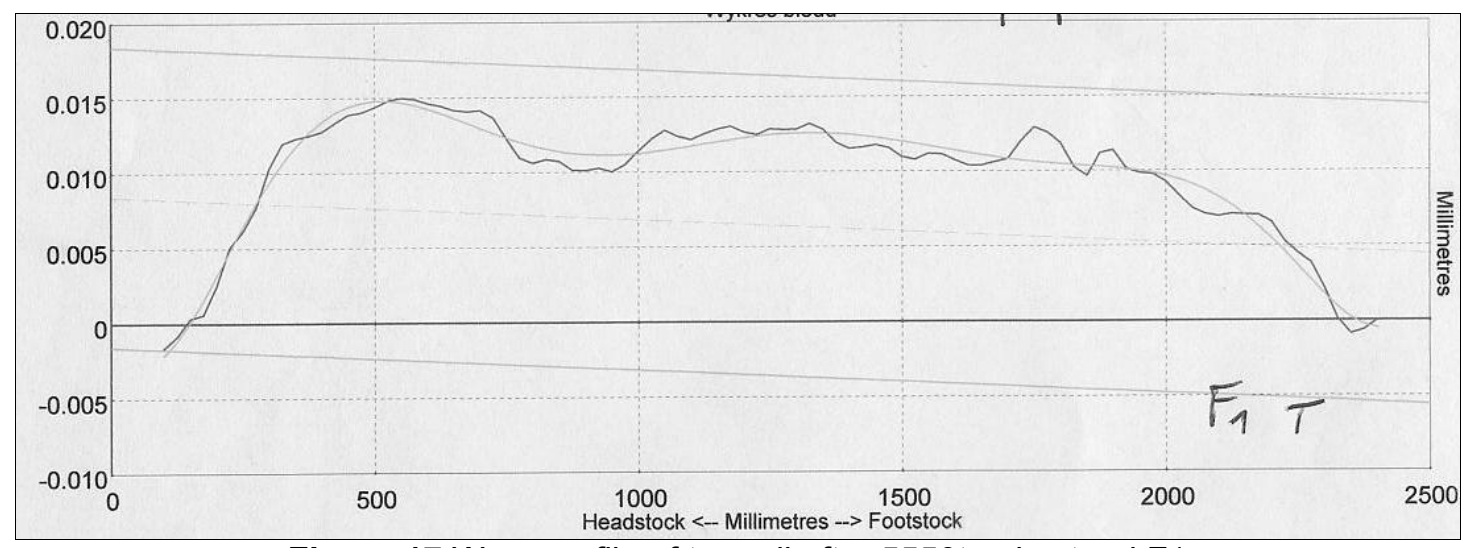

Figure 17 Wear profile of top roll after 5550ton in stand F1 


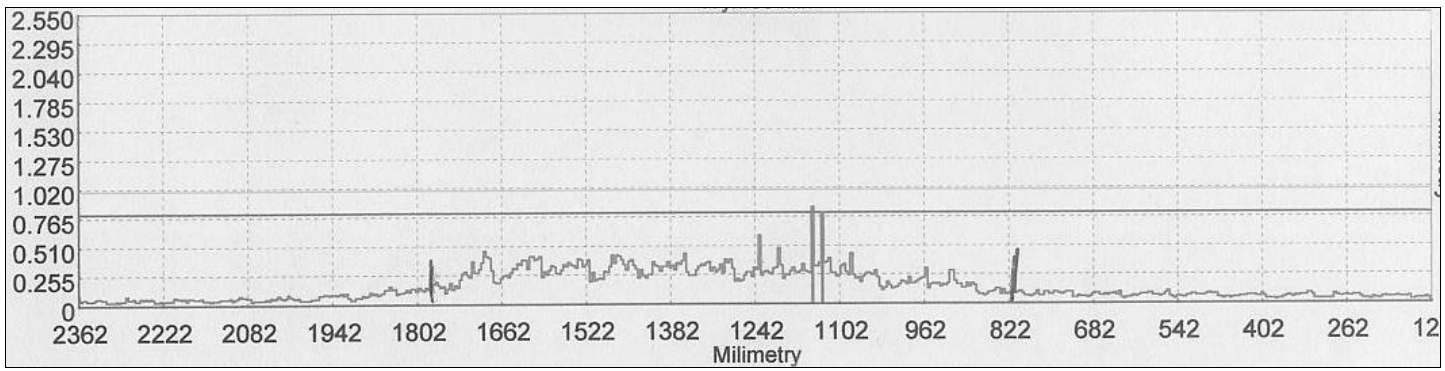

Figure 18 Bruise signal of EC system (see Figure 19)

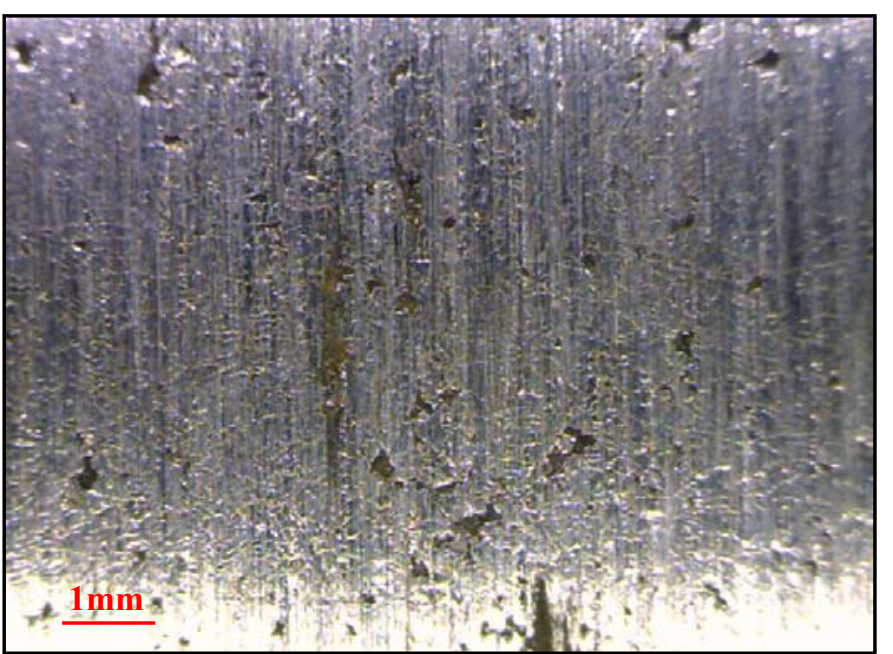

Figure 19 Aspect of the roll surface after a removal of $0.1 \mathrm{~mm}$

\section{CONCLUSION}

The main objective of this work was to present a method of analysis of the level of roll degradation using the information of EC system. This way of working can lead to good improvements in terms of reductions in removals. For example, in the mill 1 has been possible to propose new minimum thresholds of roll material removal (Table 10).

Table 10 New fixed amount of stock removal material
\begin{tabular}{|c|c|}
\hline STAND & MINIMUM STOCK REMOVAL [mm] \\
\hline F1 & 0.25 \\
\hline F2 & 0.25 \\
\hline F3 & - \\
\hline F4 & - \\
\hline
\end{tabular}

The graph called "bruise" can be very useful in following the level of residual pitting during the grinding operations.

The use of EC system also to minimize the removal of material during grinding procedures can be a valid tool to support activities regarding the redressing of the rolls. 
This system has, like first function, the individuation of roll surface defects but it can give the opportunity to evaluate the damaging of the roll surface at the end of campaign and during the grinding operations.

\section{REFERENCES}

1 M. Pellizzari et al., "Laboratory testing aimed at the development of materials for hot rolls", Proc. Steel Rolling 2006, 19-21 June, Paris, France.

2 M. Pellizzari et al., "Wear and Friction Behaviour of High Chromium Iron and High Speed Steels for Hot Rolls", Abrasion 2005, São Paulo, Brasil, 189-198. 